九州大学学術情報リポジトリ

Kyushu University Institutional Repository

Stratigraphic Equivalence and Uthofacies Comparison of the Kali Gandaki Supergroup between the Inner and Outer Lesser Himalayas in Nepal

Sakai, Harutaka

Faculty of Sciences, Kyushu University

https://doi.org/10.5109/1526117

出版情報：九州大學理學部紀要：Series D, Geology. 26 (1)，pp.69-79，1986-01-20. Faculty of Science, Kyushu University バージョン：

権利関係 : 
Mem. Fac. Sci., Kyushu Univ., Ser. D, Geol., Vol. XXVI, No. 1, pp. 69-79, text-figs. 1-4, table 1, plates 9-10, January 20, 1986

\title{
Stratigraphic Equivalence and Lithofacies Comparison of the Kali Gandaki Supergroup between the Inner and Outer Lesser Himalayas in Nepal
}

\author{
Harutaka SAKAI
}

\begin{abstract}
As the result of the investigation in the Pindi Khola valley and the upper reaches of the Andhi Khola, western Central Nepal, it was realized that the rocks of the inner belt north of the Bari Gad Fault can be grouped into four conformable lithostratigraphic units, the Belbas Slates, Syangja Beds, Darsing Dolomite, and Andhi Khola Slates in ascending order. Thereupon the stratigraphic positions and formation names of the three units mapped in my previous paper as the Virkot, the Kerabari and the Andhi Formation should be rectified as the Syangja Beds, Darsing Dolomite and Andhi Khola Slates, respectively. These three units are referable to as the stratigraphic equivalents to the Middle and Upper Members of the Chappani, Khoraidi and Ramdighat Formations in the outer belt. The Belbas Slates is comparable to the Lower Member of the Chappani. These stratigraphic equivalents between the inner and outer belts are considerably different in lithofacies from each other. Overall lithologic changes suggest that the rocks in the inner belt are the deposits in much seaward and slightly deepened environments as compared with those of the outer belt.
\end{abstract}

\section{Introduction}

With regard to studies of the geologic development of the Lesser Himalayas in Nepal, regional stratigraphic relationships between the rocks of the inner and outer belts are important but very difficult problems that confront us. No admissible accounts of the geologic framework of the two belts have so far been written. Uncertainty about the relations arises from the facts that the rocks of the two belts except the Gondwanas are unfossiliferous, and are strongly deformed.

I described the stratigraphic sequences of the late Carboniferous-Miocene Tansen Group and the Precambrian-probable early Paleozoic Kali Gandaki Supergroup on the basis of regional mapping of the Tansen and northerly adjacent Kali Gandaki river area (SAKAI, 1984; 1985). In 1985's paper I provisionally attempted to infer the stratigraphic equivalence between the rocks of the outer and inner belts, although not a few uncertainties have remained about the Kali Gandaki Supergroup in the inner belt, because the supergroup there is structurally divided into several terranes individually exhibiting strikingly different lithofacies.

$\overline{\text { Manuscript received August }} 10,1985$. 
I fortunately had an opportunity to participate in a research project "Study on the crustal movement of the Nepal Himalayas" lead by Professor K. Kizaki. My field survey was carried out in the middle reaches of the Kali Gandaki and Andhi Khola valleys for the purpose of reexamining the stratigraphy in the inner belt, and geological mapping was extended northerly to the Pindi Khola valley and northeasterly to the upper reaches of the Andhi Khola. As the results, much new information on the stratigraphy of the rocks in the inner belt was obtained, and thereby it was disclosed that the stratigraphic positions of some formations mentioned in my last paper (SAKAI, 1985) should be rectified. This paper gives the present state of understanding on the stratigraphy of the Kali Gandaki Supergroup in the inner belt and the lithologic comparison with the stratigraphic equivalents in the outer belt.

\section{Rectification of Stratigraphy of the Kali Gandaki Supergroup in the Inner Belt}

The rocks of the Kali Gandaki Supergroup in the inner belt between the Bari Gad Fault and Phalebas Thrust can be divided into four stratigraphic units: the Belbas Slates, Syangja Beds, Darsing Dolomite and Andhi Khola Slates in ascending order. The former three constitute upper half of the Middle Kali Gandaki Group, and the Andhi Khola Slates belongs to the lower part of the Upper Kali Gandaki Group. They are conformably overlain and their total thickness attains $2000 \mathrm{~m}$.

Stratigraphic positions of three formations mapped as the Andhi, the Kerabari and the Chappani in the inner belt (SAKAI, 1985, fig. 4) are rectified as follows: The Andhi Formation, which is distributed on the north of the Bari Gad Fault and in the Mradhi Khola valley (Fig. 1; SAKAI, 1985, fig. 4) is not an extension of the Kuncha Formation which is the lowermost formation of the Lesser Himalayan autochthon. It corresponds to the Ramdighat Formation in the inner belt, although both formations show different lithologies. A dolomite belt, which is separated on the south from the Andhi Formation by the Keware Fault, was identified with the Kerabari Formation (SAKAI, 1985, fig. 4). It cannot, however, be referred to as the Kerabari but to as the Khoraidi Formation. Lastly, a narrow belt of the quartzose sandstones regarded as the Virkot Formation to the south of Waling and Pindi Khola is the stratigraphic equivalent to the Chappani Formation.

\section{A. Belbas Slates and Syangja Beds}

Pinkish quartzose sandstone beds distributed in a narrow belt near Tallathum and Agredanda villages (Fig. 1) in the southern tributary areas of the Pindi and Mradhi Khola have been provisionally referred to as the Virkot Formation in SAKAI (1985). It was, however, clarified that those sandstones belong to the Chappani Formation, because they are conformably underlain by the Belbas Slates (Fig. 1). The boundary between these two units crops out on the river bank of the upper reaches of the Pindi and Mradhi Khola. 


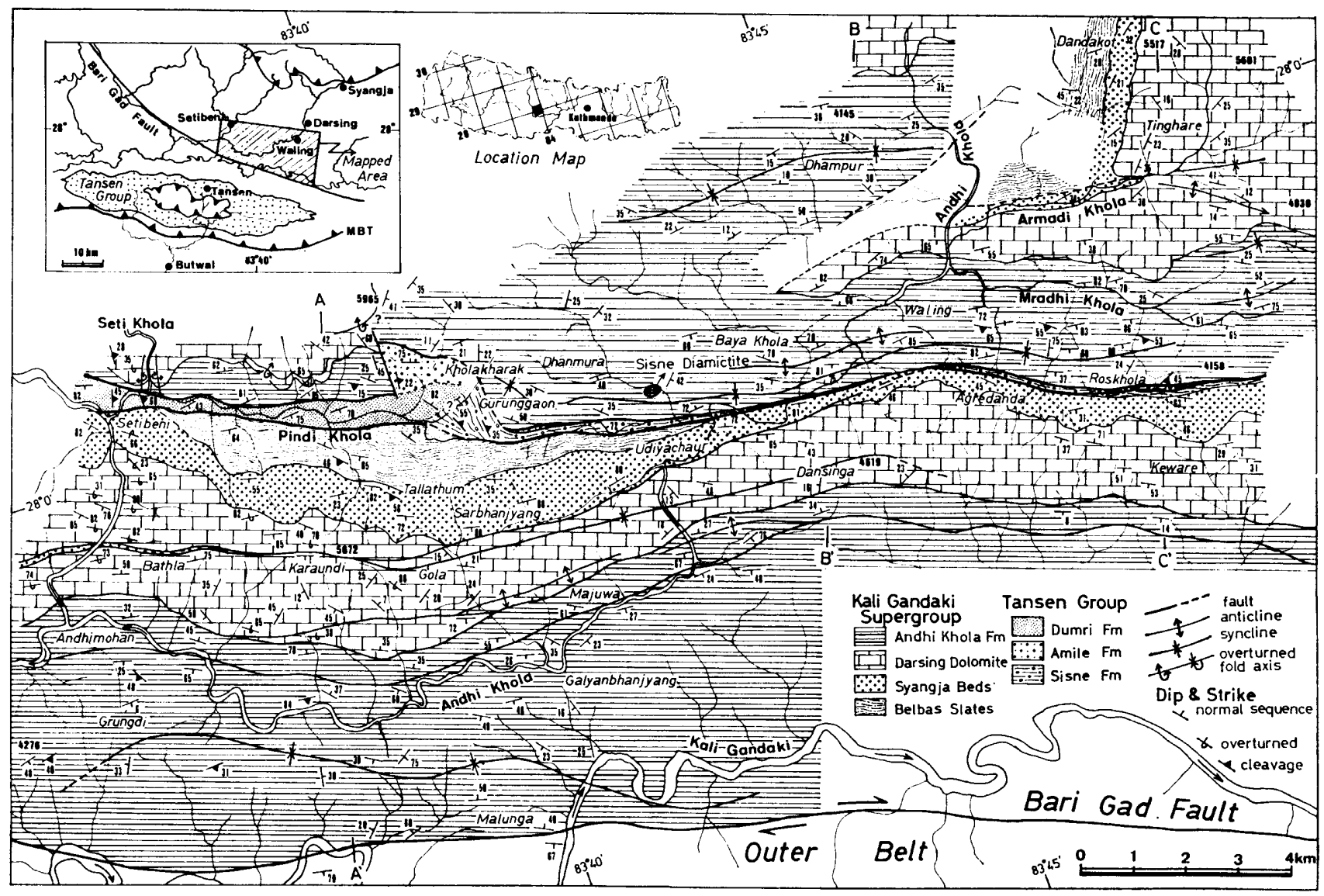

Fig. 1. Geological map of the southern part of the inner belt around the Pindi and Andhi Khola valleys. 


\section{B. Darsing Dolomite and Khoraidi Formation}

A dolomite belt which extends from the northern drainages in the lower reaches of the Andhi Khola to around Agredanda and Keware villages (Fig. 1) has been mapped as the Kerabari Formation (SAKAI, 1985). This inference has been done only on the basis of apparent lithologic similarities to the Kerabari Dolomite, although I could not examine good sections crossing this belt. My latest investigation in 1984 along the Kali Gandaki river disclosed that the dolomite belt is mainly composed of stromatolitic dolomite, and that it can be stratigraphically comparable with the Khoraidi Dolomite in the outer belt as well as Darsing Dolomite in the inner belt. Furthermore, it was ascertained that the dolomite beds are conformably underlain by the Upper Member of the Syangja Beds in the northeastern area of Agredanda, though the stratigraphic relation between both formations in the area is inferred to be in fault contact in my previous paper (SAKAI, 1985, fig. 4).

\section{Andhi Khola Formation}

A thick series of argillaceous rocks which is widely distributed along the Kali Gandaki and Andhi Khola was named the Andhi Formation, and was regarded as stratigraphically corresponding to the Kuncha Formation in the northern half of the inner belt in Central Nepal (SAKAI, 1985). Argillaceous rocks in the southern tributary area of the Mradhi Khola was also referred to as the Andhi Formation (SAKAI, 1985). However, whether or not the Andhi Formation is southern continuation of the Kuncha Formation has remained uncertain, because it is always separated by faults from other formations. My inference mentioned above was drawn from apparent lithologic similarities between the Andhi and the Kuncha Formation. The great thickness of the Andhi Formation reaching more than $1500 \mathrm{~m}$ was another reason, as no such a thick argillaceous formation is present in the outer belt. An extensive research result of Fuchs and Frank (1970) in which they regard the slate along the Kali Gandaki river as the Simla Slates (equivalent in lithologic features to the Kuncha Formation in Central Nepal) strongly drived me to judge the formation as a southern continuation of the Kuncha.

However, a conformable relationship between the Andhi Formation and the underlying Darsing Dolomite was ascertained along the northern bank of the Mradhi Khola. This stratigraphic relation implies that the Andhi Formation is correlative with the Ramdighat Formation in the outer belt, although remarkable lithologic differences between both formations are recognized as is described below.

The Andhi Formation is safely compared with the Benighat Slates (STöckLIN, 1980) in Central Nepal in that both formations are underlain by stromatolitic dolomite; Darsing in the Syangja area and Dhading in Central Nepal (Table 1) have the same lithology consisting of a very thick sequence of carbonaceous black slate.

On this occasion, I would like to change the name Andhi Formation to the Andhi Khola Formation, because the name was originally given after the Andhi Khola (Khola means river in Nepalese). 
Table 1. Lithologic differences of the Kali Gandaki Supergroup between the outer and inner belts in the western Central Nepal. The data and formation names $\left({ }^{*}\right)$ in the Kathmandu area are adopted from STöcKLIN (1980).

\begin{tabular}{|c|c|c|c|c|c|}
\hline \multicolumn{4}{|c|}{ Outer Belt } & \multicolumn{2}{|l|}{ Inner Belt } \\
\hline \multicolumn{2}{|c|}{ Formation } & Lithologic items & \multicolumn{2}{|c|}{ Lithologic Differences } & Formation \\
\hline Ke & abari & $\begin{array}{l}\text { algal structure } \\
\text { stromatolite } \\
\text { oolite } \\
\text { ripple mark } \\
\text { sun crack } \\
\text { cross-bedding } \\
\text { thickness }\end{array}$ & $\begin{array}{l}\text { common } \\
\text { rare } \\
\text { rare } \\
\text { common } \\
\text { present } \\
\text { present } \\
2000 \mathrm{~m}^{+}\end{array}$ & $\begin{array}{l}\text { rare } \\
\text { absent } \\
\text { absent } \\
\text { not reported } \\
\text { not reported } \\
\text { not reported } \\
800 \mathrm{~m} \text { in Kathmandu area }\end{array}$ & $\begin{array}{l}\text { Malekhu* } \\
\text { Limestone }\end{array}$ \\
\hline & ndighat & $\begin{array}{l}\text { colour of slate } \\
\text { lithic character } \\
\text { limestone bed } \\
\text { conglomerate } \\
\text { thickness } \\
\text { stratigrapic relation }\end{array}$ & $\begin{array}{l}\text { varicoloured (pink, red, } \\
\quad \text { purple green, white gray) } \\
\text { calcareous } \\
\text { present but thin } \\
\text { missing } \\
750 \mathrm{~m} \\
\text { conformity }\end{array}$ & $\begin{array}{l}\text { black and gray } \\
\text { argillaceous, carbonaceous } \\
\text { thick, banded } \\
\text { two boulder beds in Kathmandu area } \\
3000 \mathrm{~m} \text { in Kathmandu area } \\
\text { unconformity in Kathmandu area, } \\
\text { conformity in Syangja }\end{array}$ & $\begin{array}{l}\text { Andhi Khola } \\
\text { Formation } \\
\text { (Benighat Slates*) }^{*}\end{array}$ \\
\hline & raidi & $\begin{array}{l}\text { morphology of stromatolite } \\
\text { height of stromatolite } \\
\text { oolite } \\
\text { intraformational } \\
\text { conglomerate } \\
\text { quartzose sandstone }\end{array}$ & $\begin{array}{l}\text { subspherical to domal form } \\
\text { dominant } \\
\text { generally low } \\
\text { common, oodolosparite, } \\
\text { max thickness } 2 \mathrm{~m} \\
\text { common but very thin } \\
\text { common and thick }\end{array}$ & $\begin{array}{l}\text { columnar form dominant } \\
\text { generally high }\left(\max : 2 \mathrm{~m}^{+}\right) \\
\text {absent } \\
\text { frequent and very thick } \\
\text { present }\end{array}$ & Darsing Dolomite \\
\hline 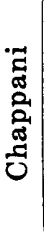 & $\begin{array}{l}\text { Uppermost } \\
\text { Member } \\
\text { Upper } \\
\text { Member } \\
\text { Lower } \\
\text { Member }\end{array}$ & $\begin{array}{l}\text { main lithology } \\
\text { main lithology } \\
\text { stromatolite }\end{array}$ & $\begin{array}{l}\text { absent } \\
\text { mainly quartzite with red- } \\
\text { purple and green slate } \\
\text { common, columnar form } \\
\text { dominant, branch form } \\
\text { present }\end{array}$ & $\begin{array}{l}\text { interlayered beds of varicoloured dolo- } \\
\text { mite, quartzite and red-purple slate } \\
\text { three thick quartzite beds, varicoloured } \\
\text { dolomite, quartzite and slate } \\
\text { rare }\end{array}$ & $\begin{array}{l}\text { Upper Memb. of } \\
\text { Syangja Beds } \\
\text { Lower Memb. of } \\
\text { Syangja Beds } \\
\text { Belbas Slates }\end{array}$ \\
\hline
\end{tabular}




\section{Lithofacies Comparison}

\section{A. Syangja Beds, Belbas Slates and Chappani Formation}

The lithologies of the Syangja Beds and Belbas Slates in the inner belt are considerably different from those of the Chappani Formation in the outer belt. Especially, the Upper Member of the Syangja Beds is unique in lithology and is characteristically pink and purple, forming good marker beds in the inner belt. It is composed of thin to thick interbeds of varicoloured dolomite, purple and lustrous slate and dolomitic quartzose sandstone. It is $280 \mathrm{~m}$ thick and divisible into two parts; slate-rich lower part and dolomite and quartzose sandstone dominating upper part as mappable units as shown in Fig. 2. A typical lithologic sequence is shown in Fig. 3. The dolomite beds are occasionally arenaceous or argillaceous, and show pink, purplish pink, white and milky white colours. Chicken-wire and similar nodular structures are common. Contained sand grains are supported by carbonate-mud matrices. Quartzose sandstones show lenticular, wavy and cross bedding. Clasts ripped up from the underlying purple slates are common in their basal part (Fig. 3). Sand grains are subrounded to rounded, and overgrowth of quartz gains with dust rings are commonly observed. It is noteworthy that many rounded potash feldspar grains are also contained.

Lithologic features mentioned above demonstrate that the member was deposited in a supratidal sabkha under arid conditions. The facies changes from the reddish rocks of the Syangja Beds to the stromatolitic Darsing Dolomite of intertidal algal-flat origin implies a transgressive sequence.

The Upper Member of the Chappani Formation in the inner belt possibly corresponds to the Lower Member of the Syangja Beds in the inner belt. The latter consists of three thick quartzose sandstone and slate interbeds, and attains a maximum thickness of $100 \mathrm{~m}$ (Fig. 2). The sandstones are mappable as

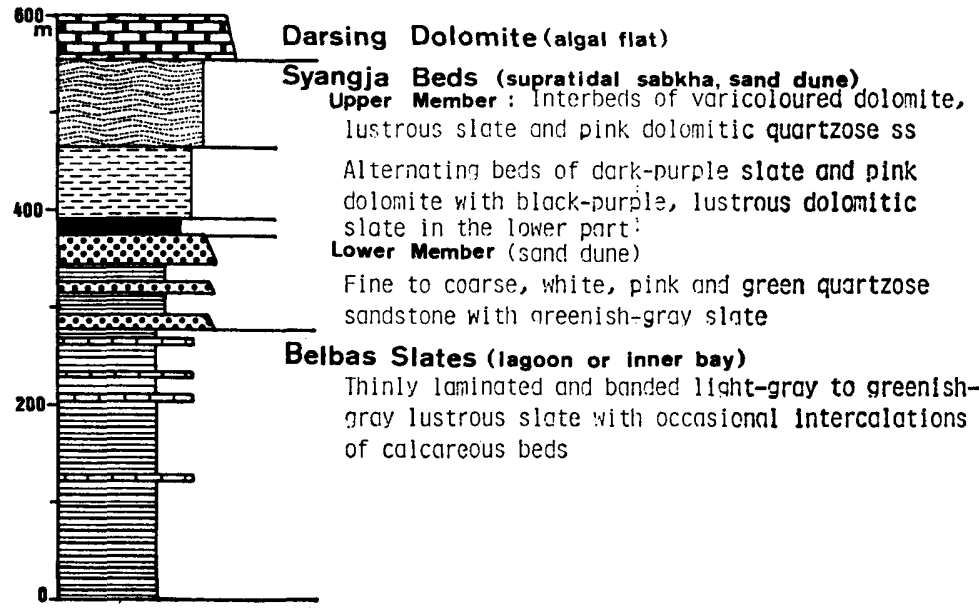

Fig. 2. Lithostratigrapic section of the Belbas Slates and Syangja Beds in the inner belt; $3 \mathrm{~km} \mathrm{SE}$ of Darsing. 
they are 10 to $40 \mathrm{~m}$ in thickness. They are well-stratified and fine-to mediumgrained. Cross-bedding including herringbone ones and ripple marks are common. They show varing colours from white to greenish-gray or pinkish tint. Quartz grains are subrounded to subangular-shaped, but pink sandstones are sometimes composed of well-rounded grains and can be called orthoquartzite. It is, therefore, difficult to distinguish them from the Virkot Quartzite only in lithology. Stratigraphic relations to the over- and underlying beds are only a certain criterion for their distinction. The slate interbeds have similar lithologies to those of the underlying Belbas Slates.

The Middle and Lower Member of the Chappani Formation in the outer belt correspond to the Belbas Slates in the inner belt around Syangja (Table. 1). However, no beds comparable with the Middle Member exhibiting rhythmically laminated, red-purple and green, calcareous slates are present in the inner belt. Furthermore stromatolitic limestones which are commonly intercalated in the Lower Member are also lacking, instead there occur some muddy limestones in the inner belt.

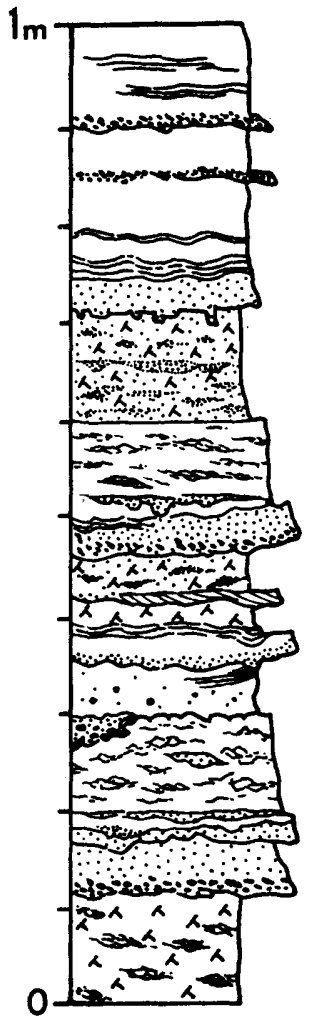

Pink dolomicrite with ripped-up

clasts of red-purple slate

Dolomitic quartzose sandstone

Red-purple slate with dispersed

sand grains and sun cracks

Pink dolomite with chicken-wire

fabric and sandy lense

Purple dolomitic sandstone

Thinly interlavered beds of redpurple slate, pink dolomicrite and dolomitic quartzose sandstone

Pink dolomicrite with chicken-wire fabric

Pink dolomitic quartzose sandstone Red-purple slate and dolomite with chicken-wire fabric

Fig. 3. Details of the typical sequence of the Upper Member of the Synagja Beds in the inner belt, showing characteristic sedimentary facies referable to sabkha deposits; south of the Pindi Khola. 


\section{B. Darsing Dolomite and Khoraidi Formation}

Both the Khoraidi Formation in the outer belt and the Darsing Dolomite in the inner belt are composed of thick cliff-forming dolomites and are nearly the same in general lithologies. However, the following minor distinctions can be recognized. First is frequent intercalation of intraformational dolomite conglomerates ( $\mathrm{Pl} .9$, Figs. 1 and 2), which amount in thickness to one-third of the formation in the inner belt. Their mode of occurrence shows that they have been derived from the underlying stromatolitic dolomite (Pl. 9, Figs. 1 and 2). Intraformational conglomerate of flat and subangular-shaped large pebbles with algal laminae are commonly interbedded with sheet-form stromatolites. Some of them keep their attitudes being about to detach from the parental stromatolitic dolomite (Pl. 9, Fig. 2). Inter-columnar pockets of stromatolites are sometimes filled with such detached flat pebbles of stromatolites (Pl. 9, Fig. 3). They must be produced by stripping from dried surfaces of stromatolite during storm. Occasional occurrence of imbricated flat-pebbles and rounded-pebbles show that pebbles had been transported by strong current. They are also common in the outer belt, but their occurrence is limited in the quartzose sandstone beds as shown in fig. 10 of SAKAI (1985). The occurrence of quartzose sandstone is less frequent than in the outer belt.

The second is lack of oolitic dolomite in the Darsing Dolomite in contrast to common occurrence of oodolosparite and arenaceous oodolosparite in the Khoraidi Dolomite of the outer belt (SAKaI, 1985). The third is seen in differences of the morphology of stromatolites. In the Khoraidi Dolomite, subspherical to low domal stromatolites are predominant, and no large columnar stromatolites were observed. On the contrary columnar to conical stromatolites are very common in the Darsing Dolomite, and some of them exceed $2 \mathrm{~m}$ in height (Pl. 10, Figs. 1 and 2). From their morphological features they seem to be referrable to Collenia symmnetrica Fenton and Fenton (Pl. 10, Fig. 1) and Colonnella sp. (Pl. 10, Fig. 2) reported from the Garhwal and Kumaon Lesser Himalayas. The replacement of stromatolitic laminae by mosaic quartz is commonly observed in the inner belt.

C. Andhi Khola and Ramdighat Formation

As mentioned above, the Andhi Khola Formation belongs to the Upper

\section{Explanation of Plate 9}

Fig. 1. Intraformational dolomite-pebble conglomerate in the Darsing Dolomite. Note smaller pebbles detached from large rubbles; Mohandanda.

Fig. 2. Imbrication of flat-pebbles which are originated from underlying stromatolitic dolomite. Largest pebble attains $30 \mathrm{~cm}$ in length. Darsing Dolomite at Karaundi.

Fig. 3. Characteristic regular banding of gray limestone and carbonaceous black limy slate of the Andhi Khola Formation in the inner belt; north of Silani.

Fig. 4. Fine laminated carbonaceous limestone of the Andhi Khola Formation in the inner belt; west of Kholakharak. 

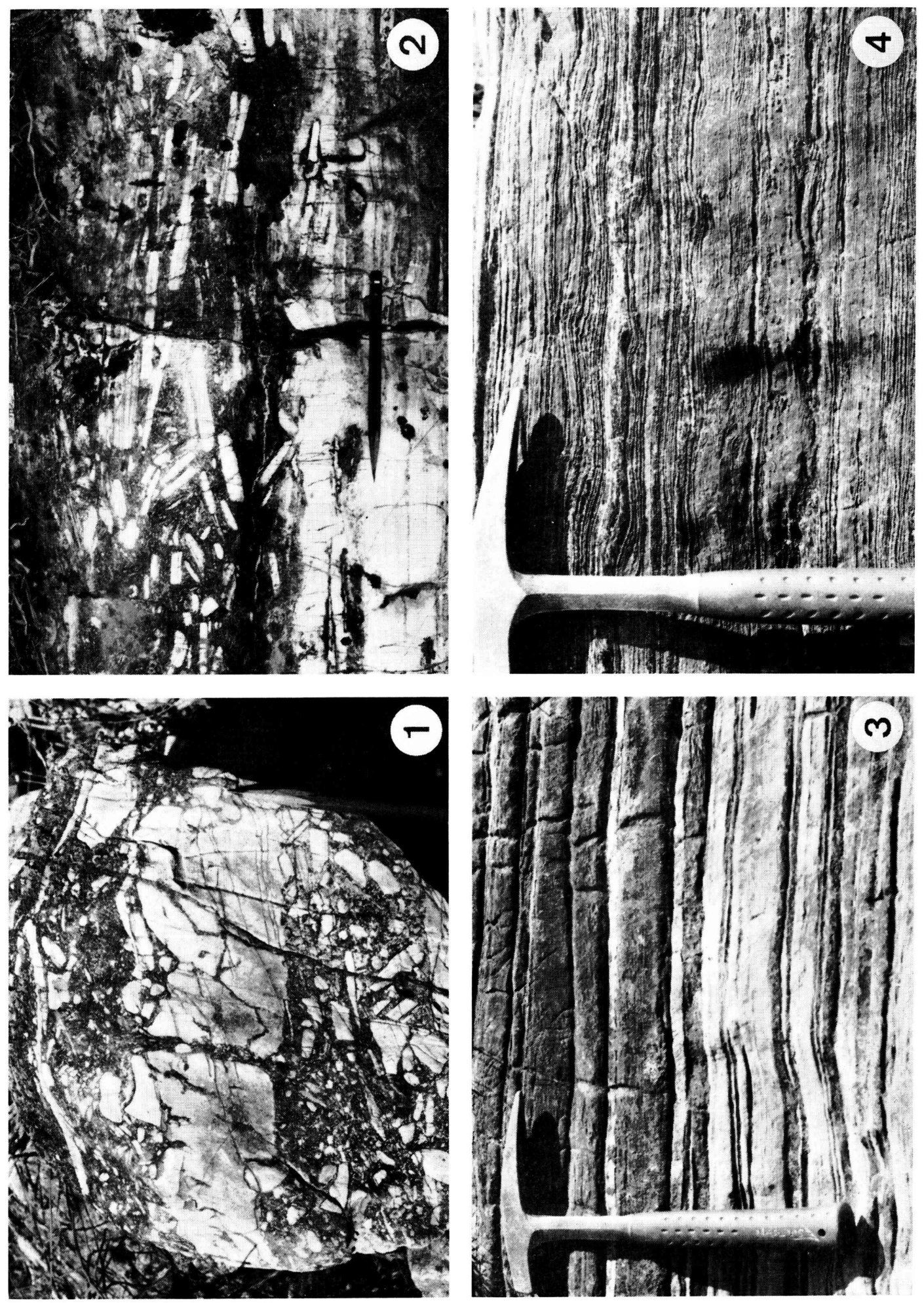

H. SAKAI: Kali Gandaki Supergroup of Inner and Outer Lesser Himalayas 

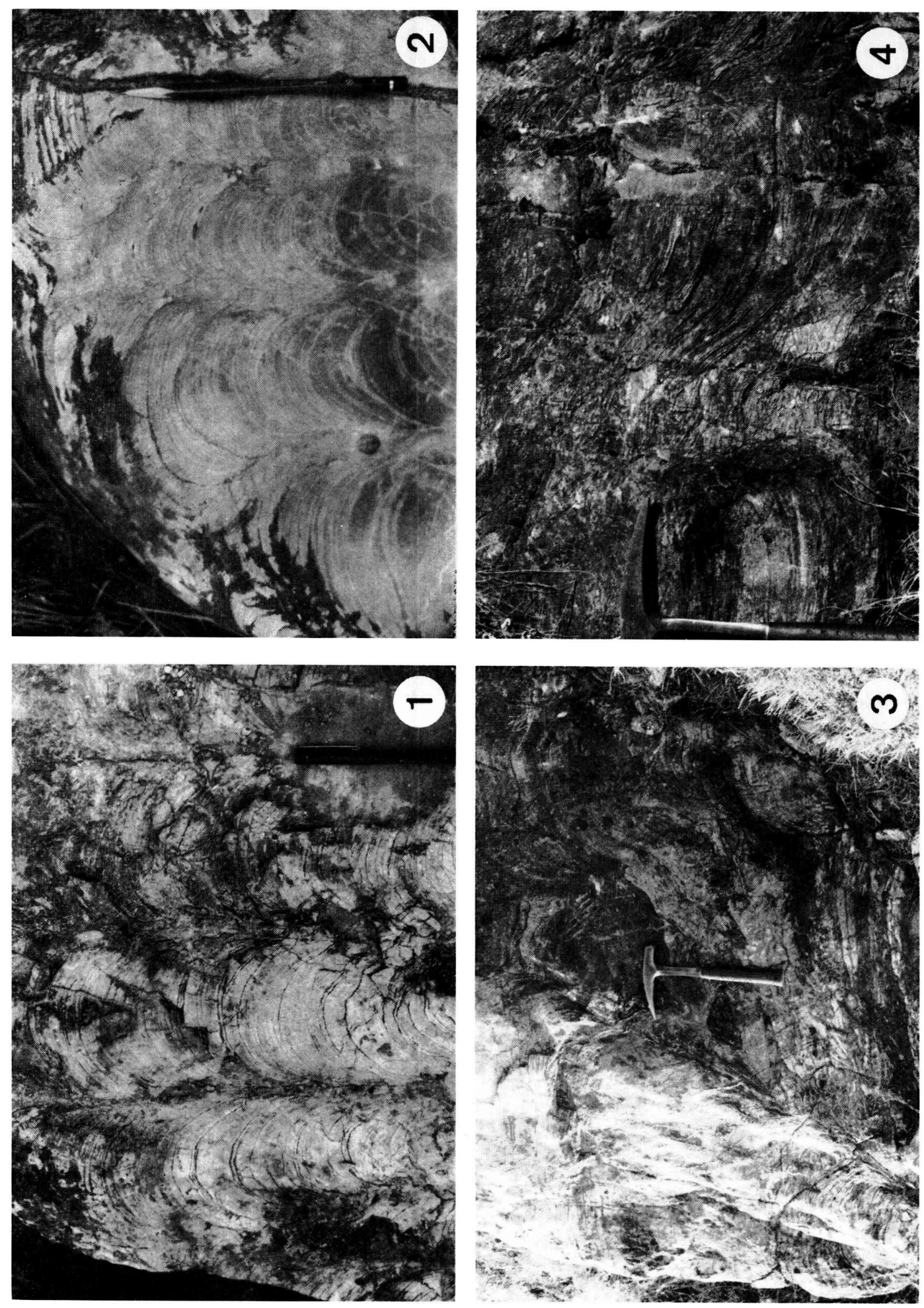

H. SAKaI: Kali Gandaki Supergroup of Inner and Outer Lesser Himalayas 
Kali Gandaki Group and is correlative with the Ramdighat Formation in the inner belt. The Ramdighat Formation is characterized by thinly interlayered beds of varicoloured calcareous slate and limestone. Thin banding of purple, pink, green, gray and white colours makes it easy to identify the formation. Scarceness of coarse clastic rocks is another important clue to identify the formation as the Ramdighat (SAKAI, 1985, fig. 11). On the contrary, the Andhi Khola Formation is a monotonous sequence consisting mostly of black slates. No beautiful colour banding as in the Ramdighat is seen. Thus the Ramdighat and Andhi Khola Formations are remarkably different in lithofacies from each other, although both are common to each other in dominantly argillaceous rocks.

The Andhi Khola Formation exceeds $900 \mathrm{~m}$ in thickness and is divisible into two members (Fig. 4). The Lower Member is composed of thin- to medium-bedded black carbonaceous slates with several argillaceous limestones and dolomitic quartzose sandstones. The slates are so massive and black as charcoal that it is difficult to find the attitudes of beds. On weathered surfaces,

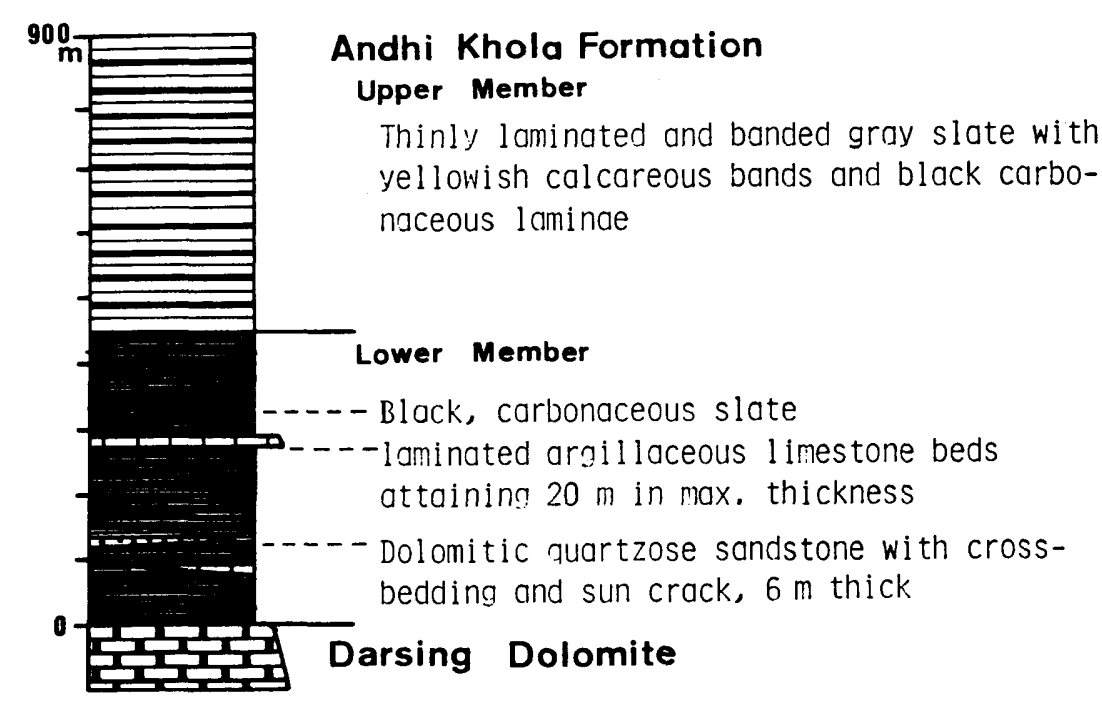

Fig. 4. Lithostratigraphic sequence of the Andhi Khola Formation (northern continuation of the Ramdighat Formation in the outer belt) in the inner belt; Mradhi valley.

\section{Explanation of Plate 10}

Fig. 1. Columnar stromatolites resemble Collenia symmetrica Fenton and Fenton. Height of columns reaches $2 \mathrm{~m}$. Darsing Dolomite; river bank of the Kali Gandaki north of Andhimohan.

Fig. 2. Columnar Colonella-type stromatolites of the Darsing Dolomite. Locality is the same as Fig. 1.

Fig. 3. Large conical stromatolites of the Darsing Dolomite. Note inter-columnar pockets filled with stromatolitic dolomite-pebbles; north of Adikaridanda.

Fig. 4. Horizontally overturned stromatolites of the Darsing Dolomite; west of Galo. 
however, fine parallel laminations are easily seen. 20 -m-thick beds of limestone are exposed along a syncline axis in the southwestern area of Waling. They show rhythmic fine banding with interlayers rich in organic matter (Pl. 9, Figs. 3 and 4). This banding has been much well-defined by differential weathering, and has resulted in jagged rock surface. Accordingly the limestones are useful as a marker bed for mapping and structural analysis of a monotonous sequence of black slates. A bed more than $5 \mathrm{~m}$ of quartzose sandstone is continuously distributed in the area of Dhampur and Dhanmura, northwestern Waling. It sometimes shows distinct cross-bedding and sun cracks.

The Upper Member is also composed of black to gray slates similar to those of the Lower Member. However, carbonaceous and calcareous layers become lesser in amount than in the Lower Member. Weathered surfaces of these layers show rhythmic colour pattern of calcareous yellow bands and carbonaceous black ones, though this colour banding is obscure on fresh exposures.

\section{Depositional Implications of Lithofacies Changes}

What do lithologic differences in the outer and inner belts of the Lesser Himalayas imply? The Lesser Himalayan rocks have a surprising lithostratigraphic consistency in the east-west direction as suggested by VALDIYA (1980). On the other hand, it was demonstrated in the Kali Gandaki and Andhi Khola valleys that lithologic changes in the north-south section are considerable. Major lithologic differences between the outer and inner belts in the western Central and Central Nepal are tabulated on Table 1. The lithologic changes from the outer to the inner belt are interpreted to imply northward deepening of depositional basins. The absence of oolitic dolomite in the Darsing Dolomite of the inner belt and common occurrenec of it in the Khoraidi Formation of the outer belt reflects that depositional environment of the rocks in the inner belt is offshore than the shoal zone only where recent oolite is formed. Increase of intraformational dolomite-pebble conglomerates in the inner belt means that their depositional sites are on a little more seaward than that of the outer belt where quartzite beds with gypsum pseudomorph are commonly intercalated. Increase of the height of stromatolites toward the north also support this interpretation.

The Ramdighat Formation in the outer belt is characterized by reddishpurple colour banding, whereas the Andhi Khola Formation and Benighat Slates in the inner belt conists of black to gray slates. This difference possibly implies that the depositional environment of the Ramdighat was under more oxidized conditions than that of the Andhi Khola and Benighat.

The Kerabari Formation in the outer belt, although it is not distributed in the surveyed area, has stromatolite and oolites, and in the uppermost beds in the type section, cross-bedding and sun cracks are observed (SAKAI, 1985). However, in the Malekhu Limestone in the inner belt of the Central Nepal, none of these rocks and sedimentary structures are reported to occur (STöcKLIN, 1980). This difference certainly indicates that the depositional site of the Kerabari Formation is on much landward side than Malekhu Limestone. This is also 
demonstrated by lithologic changes from the Malekhu Limestone to the Kerabari Dolomite. The paleocurrent directions from $\mathrm{S}$ to $\mathrm{N}$ and $\mathrm{E}$ to $\mathrm{W}$ recorded in the Kerabari Formation (SAKAI, 1985) make this interpretation much warrantable.

To sum up, the main land which supplied sediments during the deposition of the Middle and Upper Kali Gandaki Groups must have existed south to south-east of the depositional basins of these groups. This inference is consistent with the paleocurrent directions from $\mathrm{S}$ to $\mathrm{N}$ and from $\mathrm{SW}$ to $\mathrm{NE}$.

\section{Acknowledgements}

The present study is basically a part of JOCV (Japan Overseas Cooperation Volunteers) activities in the Department of Geology, Tribhuvan University. I am grateful to Dr. M. P. Sharma and other all staffs of the Department of Geology, Trichandra Campus.

Additional field investigation in 1984 was carried out as a part of the scientific expedition entitled "Study on the crustal movements in the Nepal Himalayas". I am much indebted to Prof. K. Kizaki of University of the Ryukyus and all members of the expedition for financial support and kind help.

I deeply appreciate to Prof. K. Kanmera for his valuable suggestions and critical reading of the manuscript.

\section{References}

Frank, W. and Fuchs, G. R. (1970): Geological investigations in west Nepal and their significant for the geology of the Himalayas. Geol. Rdsch., 59, 552-580.

SAKAI, H. (1985) : Geology of the Kali Gandaki Supergroup of the Lesser Himalayas in Nepal. Mem. Fac. Sci., Kyushu Univ. [D], 25, (3), 337-397.

SAKAI, H. (1986) : Overfolds and block-faults in the frontal part of the Inner Lesser Himalayas, western Central Nepal. Mem. Fac. Sci., Kyushu Univ. [D], 26, (this volume) (1), 81-93.

StöckLIN (1980): Geology of Nepal and its Regional Frame. Jour. Geol. Soc. London, $137,1-34$.

VALDIYA, K. S. (1980a): Stratigraphy of the Lesser Himalaya: Synthesis. In: VAldiYA, K. S. and Bhatia, S. B. (eds.), Stratigraphy and Correlations of Lesser Himalayan Formations. Hindustan Publ. Delhi, 283-296. 